\title{
TOXICOLOGICAL STUDIES OF SOME NEW AMIDES OF SULPHOSALICYLIC ACID IN INSECTS
}

\author{
ARVIND KUMAR ${ }^{1}$, SUDHIR TRIPATHI ${ }^{2}$, ROHIT K.SINGH ${ }^{3}$, MANOJ KUMAR ${ }^{4}$ \\ 1Department of Chemistry, Narain P.G.College, Shikohabad, U.P. \\ 2Department of Chemistry, D.B.S.P.G.College, Kanpur, U.P. \\ 3Department of Chemistry, Jawaharlal Nehru P.G.College, Banda, U.P. \\ ${ }^{4}$ Department of Chemistry, Bhabha Institute of Technology, Kanpur, U.P. \\ *Corresponding author. E-mail: arvindkumarskb@gmail.com
}

Received: October 31, 2011; Accepted: November 14, 2011

\begin{abstract}
The present manuscript covers the toxicological studies of some amides of sulphosalicylic acid which are synthesized by reported method using reaction of suitable amines with 5-sulphosalicylic acid in 2:1 ratio and are found highly effective against different biological system.
\end{abstract}

Keywords: sulphosalicylic acid, contact toxicity, stomach toxicity, antifeedant and acaricidal activity.

\section{Introduction}

Nitrogen and sulphur containing organic compounds plays an important role, not only in life science but also in many other industrial fields related to special and fine chemistry. It is well known in literature that nitrogen and sulfur containing compounds are essentially used in medical purpose for the treatment of different kinds of fungal and bacterial infections along with treatment of various kinds of acute diseases. The organic moiety having nitrogen and sulfur atom results towards higher efficiency against various diseases because sulfur is capable to interaction with receptor [1-4]. Therefore highly used in the treatment of various tumors along with gastric ulcers [5-9]. We have already reported the synthesis and biological activity of some nitrogen and sulphur based compounds in recent and the present manuscript covers the part of that work which was not published earlier.

\section{EXPERIMENTAL}

The synthesis of these compounds was reported by our group earlier [10]. The compounds were generally synthesized by the reaction of 5-sulphosalicylic acid with respective amine in $(1: 2)$ ratio in ethanol. The compounds are crystalline solids and stable at room temperature. The experiments regarding toxicological activity on insects and mites are given as under.

\section{Contact toxicity}

The contact toxicity of these compounds was tested by the topical application method [11]. Fourth instar larvae of Spodoptera litura were used for this purpose. About 30 larvae were used for each concentration. The compounds were first dissolved in acetone and different concentrations were prepared. Now each concentrations were applied on the dorsal surface of the larvae (about
$10 \mu \mathrm{l}$ in each larvae separately). Insects treated only with acetone are served as control and left for $24 \mathrm{hrs}$. After 24 hrs the mortality was recorded and treatment mortality was corrected with the control mortality. These mortality data were used for calculating $\mathrm{LC}_{50}$.

\section{Stomach toxicity}

The stomach toxicity of these compounds was tested by the leaf-dip method [12]. In this technique, the leaf discs of about $25 \mathrm{~cm}^{2}$ were prepared out of caster leafs and were dipped for $30 \mathrm{sec}$ in various concentration of the test compounds. (The compounds were dissolved in acetone and various concentrations were prepared). The leaf discs dipped only in acetone alone are served as control. Now air dried the leaf discs to evaporate the excess acetone. The fourth instar larvae of Spodoptera litura were used for this purpose ten larvae were used for each replication and three replications were used (maintained) for each concentration. The dried leaf discs were now offered for feeding. The mortality was recorded after $24 \mathrm{hrs}$ and treatment mortality was corrected with control mortality. The mortality data were used for calculating $\mathrm{LC}_{50}$.

\section{Antifeedant activity}

The antifeedant activity of these compounds was tested by the leaf dip method [12]. In this method the leaf discs of about $25 \mathrm{~cm}^{2}$ were prepared out of caster leaf and were dipped for 30 seconds in various concentrations of the test compounds (The compounds were dissolved in acetone and various concentrations were prepared). The leaf discs dipped only in acetone alone were served as control. Now air dried the leaf discs to evaporate the excess acetone. The fourth instar larvae of Spodoptera litura were used for this purpose. Ten larvae were used for each replication and three replications were used for 
each concentration. The dried leaf discs were offered for feeding and allowed to feed for $24 \mathrm{hrs}$; after 24 hrs the leaf area uneaten was measured using leaf area meter. The difference between leaf area provided and the leaf are left over was taken as amount of leaf area consumed. The feeding inhibition was calculated is used for calculating the $\mathrm{EC}_{50} / \mathrm{LD}_{50}$ value.

\section{Acaricidal Activity}

The acaricidal activity of these compounds was tested by leaf dip method [12]. In this method, the compound was dissolved in distilled water or acetone and different concentrations were prepared using $0.2 \%$ tween 20 as emulsifier. The leaf discs of mulberry $\left(5 \mathrm{~cm}^{2} \mathrm{dia}\right)$ were dipped in different concentrations for 30 seconds. Now air dried and placed over wet cotton in Petri dishes. Adult's female mites (Tetranychus species) were released on treated leaf discs and mortality was recorded after $48 \mathrm{hrs}$ after treatment. These mortality data were used for calculation of the $\mathrm{LC}_{50} / \mathrm{LD}_{50}$ value.

\section{RESULTS AND DISCUSSION}

All the compounds were crystalline solid and quite stable at room temperature with good yield (70-75\%). The compounds were soluble in polar solvents. They have sharp melting points. The molecular weights of the compounds were determined cryoscopically and their infra red spectra (FTIR) were recorded in a Perkin-Elmer spectrophotometer in $4000-200 \mathrm{~cm}^{-1}$ range. The structures of the synthesized compounds are given below.<smiles>COc1ccc(NC(=O)c2cc(S(=O)(=O)Nc3ccc(OC)cc3)ccc2O)cc1</smiles>

\section{[1] $\mathrm{C}_{21} \mathrm{H}_{20} \mathrm{~N}_{2} \mathrm{O}_{6} \mathrm{~S}$}<smiles>O=C(Nc1ccccn1)c1cc(S(=O)(=O)Nc2ccccn2)ccc1O</smiles>

[2] $\mathrm{C}_{17} \mathrm{H}_{14} \mathrm{~N}_{2} \mathrm{O}_{4} \mathrm{~S}$<smiles>O=C(Nc1ccccc1)c1cc(S(=O)(=O)Nc2ccccc2)ccc1O</smiles>

[3] $\mathrm{C}_{18} \mathrm{H}_{16} \mathrm{~N}_{4} \mathrm{O}_{4} \mathrm{~S}$<smiles>O=C(Nc1cccc2ccccc12)c1cc(S(=O)(=O)Nc2cccc3ccccc23)ccc1O</smiles><smiles>O=C(Nc1ccc(Cl)cc1)c1cc(S(=O)(=O)Nc2ccc(Cl)cc2)ccc1O</smiles>

[5] $\mathrm{C}_{19} \mathrm{H}_{14} \mathrm{~N}_{2} \mathrm{O}_{4} \mathrm{SCl}$<smiles>NNC(=O)c1cc(S(=O)(=O)NN)ccc1O</smiles>

[6] $\mathrm{C}_{7} \mathrm{H}_{10} \mathrm{~N}_{4} \mathrm{O}_{4} \mathrm{~S}$

\section{Contact Toxicity}

The contact toxicity of these compounds was tested against the fourth instar larvae of Spodoptera litura using different concentration of the test compounds in acetone by adding tween 20 emulsifier. The mortality data was used for calculating $L_{5} C_{50} / L_{50}$ of respective compounds. It was found that compounds show higher activity against the larvae of insects. The activity again depends on the constituents atoms of the compound that is the presence of nitrogen, Sulphur along with polar groups increases the activity against the insect by creating the spasmic condition.

\section{Stomach toxicity}

The stomach toxicity of these compounds was checked against the same larvae of insect, Spodoptera litura using different concentration of the compounds in acetone and by adding tween 20 as emulsifier. The mortality data were used to calculate $\mathrm{LC}_{50} / \mathrm{LD}_{50}$ value. It was found that activity of the compounds show highest mortality. The presence of nitrogen, Sulphur along with polar groups increases the activity against the insect by creating the spasmic condition.

\section{Antifeedant Activity}

Antifeedant activity of these compounds was evaluated against fourth instar larvae of Spodoptera litura using different concentration of the test compound in acetone by adding tween 20 as emulsifier. Mortality data was used to calculate the $\mathrm{LC}_{50} / \mathrm{LD}_{50}$ of the respective compounds. All the respective compounds show remarkable antifeedant activity against the insect.

\section{Acaricidal Activity}

The acaricidal activity of these compounds was assayed against Tetranychus species of mites. Different concentrations of the compounds were prepared in acetone and by adding tween 20 as emulsifier. Approximately all these compounds show moderate to higher activity against mites. The constituents atoms of the compound that is the presence of nitrogen, Sulphur along with polar groups increases the activity against the insect by creating the spasmic condition. 
References

[1] Chakraborty A. and Chaterjee M. (1994) Neoplasma, 41, 291-296.

[2] Cruz T.F., Morgon A. and Min W. (1995) Mol. Biochem, 153, 161-166.

[3] Chitamber C.R. and Wereley J.P. (1997) J. Biol. Chem., 272, 12151-12157.

[4] Collery P., Millart H., Pluot M. and Anghileri L.J. (1986) Anticancer. Res., 6, 1085-1088.

[5] Tajmir-Riahi H.A., Naovi M. and Ahmad R. (1990) Toxicol. Appl. Pharmacol; 106, 462-468.

[6] Barone G., Ramusino M.C., Barbieri R. and Manna G.L. (1999) J. Mol. Struct, 469, 143.

[7] Kayser F., Biesemans M., Gielen M. and Willem R. (1994) Magn. Reson. Chem., 32, 358.
[8] Mishra Anjali, Singh R.K., Singh S., Mishra A., Kumar M., Kant Ravi and Thakur R.S. (2009) Int. J. Of Pharmaceutical Analysis, 1(2), 1-3.

[9] Bishayee A., Karmaker R., Mandal A., Kundu S.N. and Chaterjee M. (1997) Eur. J. Cancer. Prev. $6,58-70$.

[10] Mishra Anjali, Kumar Manoj, Mishra Ashok, Kumar Arvind, Kant Ravi and Thakur R.S. (2010) Inter. Jour. Chem. Reser., 2(1), 28-31.

[11] Dethie V.G., Browne L.B., Smith C.N.(1960) J. Econ. Entomol. 53, 134-136.

[12] Deshmukh S.D., Borle M.N. (1976) Ind. J. Entomol. 37(1), 11-18.

Table 1- Contact toxicity at $24 \mathrm{hrs}$

\begin{tabular}{|c|l|c|c|c|c|}
\hline $\begin{array}{c}\text { S. } \\
\text { No. }\end{array}$ & \multicolumn{1}{|c|}{ Compounds } & Fiducial limits & Slope & Chi-square & $\begin{array}{c}\text { LC } \text { Fo }_{\text {LD }} \\
\text { hrs }\end{array}$ \\
\hline 1. & $\mathrm{C}_{21} \mathrm{H}_{20} \mathrm{~N}_{2} \mathrm{O}_{6} \mathrm{~S}$ & $0.48-0.75$ & $1.61 \pm 0.16$ & $2.94(3)$ & 0.59 \\
\hline 2. & $\mathrm{C}_{17} \mathrm{H}_{14} \mathrm{~N}_{2} \mathrm{O}_{4} \mathrm{~S}$ & $0.40-0.59$ & $1.66 \pm 0.15$ & $5.66(3)$ & 0.48 \\
\hline 3. & $\mathrm{C}_{18} \mathrm{H}_{16} \mathrm{~N}_{4} \mathrm{O}_{4} \mathrm{~S}$ & $0.29-0.39$ & $1.97 \pm 0.16$ & $4.39(3)$ & 0.34 \\
\hline 4. & $\mathrm{C}_{27} \mathrm{H}_{20} \mathrm{~N}_{2} \mathrm{O}_{4} \mathrm{~S}$ & $1.87-12.08$ & $1.09 \pm 0.19$ & $1.60(3)$ & 3.53 \\
\hline 5. & $\mathrm{C}_{19} \mathrm{H}_{14} \mathrm{~N}_{2} \mathrm{O}_{4} \mathrm{SCl}$ & $1.33-3.99$ & $1.32 \pm 0.20$ & $2.38(3)$ & 2.01 \\
\hline 6. & $\mathrm{C}_{7} \mathrm{H}_{10} \mathrm{~N}_{4} \mathrm{O}_{4} \mathrm{~S}$ & $1.61-9.55$ & $1.01 \pm 0.17$ & $0.68(3)$ & 2.97 \\
\hline
\end{tabular}

Table 2-Stomach toxicity data at $24 \mathrm{hrs}$

\begin{tabular}{|c|l|c|c|c|c|}
\hline $\begin{array}{c}\text { S. } \\
\text { No. }\end{array}$ & \multicolumn{1}{|c|}{ Compounds } & Fiducial limits & Slope & Chi-square & $\begin{array}{c}\text { LC } \text { Fo }^{\text {LD }} \\
\text { hrs. }\end{array}$ \\
\hline 1. & $\mathrm{C}_{21} \mathrm{H}_{20} \mathrm{~N}_{2} \mathrm{O}_{6} \mathrm{~S}$ & $0.57-1.05$ & $1.32 \pm 0.15$ & $0.63(3)$ & 0.74 \\
\hline 2. & $\mathrm{C}_{17} \mathrm{H}_{14} \mathrm{~N}_{2} \mathrm{O}_{4} \mathrm{~S}$ & $054-0.90$ & $1.49 \pm 0.16$ & $3.39(3)$ & 0.68 \\
\hline 3. & $\mathrm{C}_{18} \mathrm{H}_{16} \mathrm{~N}_{4} \mathrm{O}_{4} \mathrm{~S}$ & $0.49-0.77$ & $1.57 \pm 0.16$ & $2.79(3)$ & 0.60 \\
\hline 4. & $\mathrm{C}_{27} \mathrm{H}_{20} \mathrm{~N}_{2} \mathrm{O}_{4} \mathrm{~S}$ & $0.86-1.99$ & $1.28 \pm 0.16$ & $0.80(3)$ & 1.20 \\
\hline 5. & $\mathrm{C}_{19} \mathrm{H}_{14} \mathrm{~N}_{2} \mathrm{O}_{4} \mathrm{SCl}$ & $1.61-9.55$ & $1.01 \pm 0.17$ & $0.68(3)$ & 2.97 \\
\hline 6. & $\mathrm{C}_{7} \mathrm{H}_{10} \mathrm{~N}_{4} \mathrm{O}_{4} \mathrm{~S}$ & $0.82-1.67$ & $1.45 \pm 0.17$ & $0.65(3)$ & 1.10 \\
\hline
\end{tabular}

Table 3-Antifeedant activity at $24 \mathrm{hrs}$.

\begin{tabular}{|c|l|c|c|c|c|}
\hline $\begin{array}{c}\text { S. } \\
\text { No. }\end{array}$ & \multicolumn{1}{|c|}{ Compounds } & Fiducial limits & Slope & Chi-square & $\begin{array}{c}\text { LC }_{50} / \text {LD }_{50} \text { at 24 } \\
\text { hrs. }\end{array}$ \\
\hline 1. & $\mathrm{C}_{21} \mathrm{H}_{20} \mathrm{~N}_{2} \mathrm{O}_{6} \mathrm{~S}$ & $0.62-1.46$ & $1.05 \pm 0.46$ & $1.09(3)$ & 0.87 \\
\hline 2. & $\mathrm{C}_{17} \mathrm{H}_{14} \mathrm{~N}_{2} \mathrm{O}_{4} \mathrm{~S}$ & $0.84-2.34$ & $1.06 \pm 0.15$ & $0.70(3)$ & 1.24 \\
\hline 3. & $\mathrm{C}_{18} \mathrm{H}_{16} \mathrm{~N}_{4} \mathrm{O}_{4} \mathrm{~S}$ & $0.43-0.87$ & $1.03 \pm 0.14$ & $0.34(3)$ & 0.58 \\
\hline 4. & $\mathrm{C}_{27} \mathrm{H}_{20} \mathrm{~N}_{2} \mathrm{O}_{4} \mathrm{~S}$ & $0.30-0.48$ & $1.25 \pm 0.14$ & $3.48(3)$ & 0.37 \\
\hline 5. & $\mathrm{C}_{19} \mathrm{H}_{14} \mathrm{~N}_{2} \mathrm{O}_{4} \mathrm{SCl}$ & $0.71-2.21$ & $0.89 \pm 0.14$ & $0.20(3)$ & 1.08 \\
\hline 6. & $\mathrm{C}_{7} \mathrm{H}_{10} \mathrm{~N}_{4} \mathrm{O}_{4} \mathrm{~S}$ & $0.49-1.25$ & $0.87 \pm 0.13$ & $0.89(3)$ & 0.71 \\
\hline
\end{tabular}

Table 4-Acaricidal activity at $24 \mathrm{hrs}$

\begin{tabular}{|c|l|c|c|c|c|}
\hline $\begin{array}{c}\text { S. } \\
\text { No. }\end{array}$ & \multicolumn{1}{|c|}{ Compounds } & Fiducial limits & Slope & Chi-square & $\begin{array}{c}\text { LC }_{50} / \text {LD }_{50} \text { at 24 } \\
\text { hrs. }\end{array}$ \\
\hline 1. & $\mathrm{C}_{21} \mathrm{H}_{20} \mathrm{~N}_{2} \mathrm{O}_{6} \mathrm{~S}$ & $0.05-0.09$ & $1.16 \pm 0.09$ & $12.57(3)$ & 0.07 \\
\hline 2. & $\mathrm{C}_{17} \mathrm{H}_{14} \mathrm{~N}_{2} \mathrm{O}_{4} \mathrm{~S}$ & $0.05-0.10$ & $0.87 \pm 0.07$ & $20.01(3)$ & 0.07 \\
\hline 3. & $\mathrm{C}_{18} \mathrm{H}_{16} \mathrm{~N}_{4} \mathrm{O}_{4} \mathrm{~S}$ & $0.04-0.09$ & $0.70 \pm 0.06$ & $4.61(3)$ & 0.05 \\
\hline 4. & $\mathrm{C}_{27} \mathrm{H}_{20} \mathrm{~N}_{2} \mathrm{O}_{4} \mathrm{~S}$ & $0.05-0.10$ & $0.97 \pm 0.08$ & $13.22(3)$ & 0.07 \\
\hline 5. & $\mathrm{C}_{19} \mathrm{H}_{14} \mathrm{~N}_{2} \mathrm{O}_{4} \mathrm{SCl}$ & $0.12-0.26$ & $0.89 \pm 0.08$ & $8.52(3)$ & 0.17 \\
\hline 6. & $\mathrm{C}_{7} \mathrm{H}_{10} \mathrm{~N}_{4} \mathrm{O}_{4} \mathrm{~S}$ & $0.08-0.20$ & $0.75 \pm 0.07$ & $5.53(3)$ & 0.12 \\
\hline
\end{tabular}

